succeeded in raising $\$ 41.4$ million in outside capital and equity. Moreover, the programme apparently created jobs. The 11 firms had employed 261 people in 1977; by 1982 they employed 616 people. The most spectacular growth was in a genetic engineering firm, Collaborative Research of Lexington, Massachusetts, which received $\$ 25,000$ in seed money in 1977 and by 1982 had raised $\$ 24.9$ million from outside sources.

The Rudman bill made a spectacular passage through the Senate in December. Of the Senate's 100 members, 85 were cosponsors of the bill, and it passed by a vote of 90 to 0 . One modification exempted the $\$ 10,000$ million in-house federal research and developement from the calculation. A second modification was an amendment introduced by Senator Harrison Schmitt limiting the amount of funds to be set aside that could be taken from federal basic research budgets. This amendment was an attempt to placate spokesmen for the basic research community and univerisities who attacked the bill as a raid on basic research funds. They argued that development work in most federal agencies has powerful protectors, whereas basic research does not. In the Department of Defense, for example, the contractors and armed services buying the MX missile, or Trident submarine, would keep their research and development funds from the amount set aside, so that the basic research funded by the Department of Defense would be unduly tithed.

One fear being raised by university spokesmen is that the small firms' share of the federal research and development pie will grow, at the universities' expense. The proposed one per cent sounds modest enough, but any amount would take some funds away from federal basic research at a time when such money is becoming scarce.

Some university spokesmen argue that small firms do not do basic research of high enough quality to qualify for federal funds, and that a set-side programme will allow them to adhere to this lower standard. They argue that such firms should compete with universities and other traditional research groups. Several federal agencies prohibit for-profit firms from applying for research grants, although the National Institutes of Health has now lowered this barrier.

In the coming weeks the House will have to decide which version of the legislation it will pass. The variant most palatable to university spokesmen is that proposed by Don Fuqua, chairman of the House Science and Technology Committee. This would leave oversight of the programme to the authorizing committees of Congress for each of the federal agencies involved, thus allowing them to devise individual setaside programmes or exempt the agencies under their jurisdiction.

The version most likely to pass, however, is a bill put forward by John $\mathbf{J}$. LaFalce, which is modelled on the original
Rudman bill but is even friendlier to small business. The LaFalce version would make the money set aside not one, but three per cent of all federal research and development, and does not exempt federal in-house research from the calculation. The LaFalce version would make $\$ 1,200$ million available to the small firms in the first year - contrasting with the more cautious Rudman bill, which phases in the programme, reaching the $\$ 300$ million level in the third year. But in view of the opposition to the set-asides that has surfaced elsewhere in the House, it seems likely that the LaFalce forces would be satisfied with a final version limiting the set-aside to one per cent, having a threeyear phase in period, and a feature limiting the "raid" on basic research.

\section{Deborah Shapley}

\section{Polish Academy of Sciences Slow progress}

Poland's new legislation on the Academy of Sciences will ensure parity of funding for the institutes of the academy and the research institutes of the production ministries, according to Warsaw radio. A main concern of Polish scientists has been the lack of separate budgets for the various institutes funded on the principle of dividing research into "problems" funded nationally. The new bill, which is under discussion by the Council of Ministers (Cabinet), thus seeks to redress one of the major grievances of the academy scientists expressed at last September's National Congress of Solidarity in Gdansk. It therefore forms part of a current tacit policy on the part of the ruling Military Council for National Salvation (WRON) to grant various "social" demands from the Solidarity programme while keeping open the question of the future of the independent trade union movement.

Much, however, remains uncertain, and nothing has been announced so far about one of the most contentious issues - the status of the Secretary of the academy. At present, the incumbent of this post holds quasi-ministerial rank, and is responsible in the first instance to the prime minister, not to his fellow academicians. During "renewal", as part of the nationwide drise towards "self-governance", there were strenuous moves (headed by the academy lobby within Solidarity) to change this anomalous state of affairs and ensure greater autonomy for the academy, thus ending the long-standing friction between the members and scientific employees of the academy on the one hand, and the academy bureaucrats on the other.

There has also been no news since the military council took power of many other proposed reforms, despite their apparent innocuousness. For example, it was proposed that the academy should decide, on purely academic grounds, whether or

\section{Call from arms}

\section{Washington}

At its annual meeting in Washington the National Academy of Sciences (NAS) made one of its rare ventures into public policy pronouncements. The assembled members adopted a resolution calling on the President and Congress and their counterparts in the Soviet Union "to intensify efforts to achieve an equitable and verifiable agreement"' limiting strategic arms, and to "reduce significantly the number of nuclear weapons and delivery systems". The resolution further urged them to reduce the risk of accidental war, to inhibit proliferation of nuclear weapons, and to "continue and observe" all arms control agreements including Salt II, signed by the United States and the Soviet Union in 1979 but not ratified by Senate. Finally NAS urges the avoidance of "military doctrines that treat nuclear explosives as ordinary weapons of war".

The NAS resolution makes no mention of the "nuclear freeze" urged by other groups around the country. It was passed almost unanimously, with a few abstentions and one dissenting vote. Proposer for the resolution was Marvin Goldberger, president of California Institute of Technology and chairman of the academy's Committee on International Security and Arms Control. The resolution was sent to the President via his science adviser, George A. Keyworth II.

Deborah Shapley

not its members should be able to travel abroad. At present, non-scientific criteria still play a major role in such decisions. The emergency regulations on foreign travel for scientists stress that the would-be traveller must be given a thorough political vetting.

Not surprisingly, this can pose problems for academy scientists. A case in point is that of Artur Swiergiel, a young physiologist who, since last October, has been researching at the Babraham Institute of Animal Physiology in Cambridge.

Mr Swiergiel had a six-month scholarship under an agreement between the British Council and the Polish Academy of Sciences. Last November, realizing that he would need extra time for his experiments, $\mathrm{Mr}$ Swiergiel applied for an extension. On 31 March, he received a telegram from Professor Maciej Zurkowski, director of the academy's Institute of Animal Breeding and Genetics, confirming the extension. Three weeks later, a second telegram arrived, stating that Professor Zurkowski had been informed by "the academy" that the extension had been refused. No explanation was given - but $\mathrm{Mr}$ Swiergiel had formerly served on the Warsaw regional executive of Solidarity.

Vera Rich 